\title{
Resolution of inflammation: from basic concepts to clinical application
}

\author{
Markus F. Neurath ${ }^{1,2}$ \\ Published online: 23 November 2019 \\ (C) Springer-Verlag GmbH Germany, part of Springer Nature 2019
}

Acute inflammation may protect the body from invading bacteria or viruses and can help to overcome injuries. While such acute inflammatory processes are usually self-limiting and are followed by tissue repair and healing responses, there are some circumstances in which acute inflammation fails to resolve and is subsequently followed by development of chronic inflammation $[1,2]$. Chronic inflammatory disorders place a major burden [3, 4] on affected patients and the responsible health care systems. Key inflammatory disorders in this context comprise various diseases such as psoriasis [5], pemphigus vulgaris [6], graft versus host disease [7], allergic asthma [8], rheumatoid arthritis [9], lupus erythematosus [10], neuroinflammatory disorders [11] and multiple sclerosis [12], uveitis [13], Crohn's disease [14], and ulcerative colitis [15]. In addition, atherosclerosis has been identified as a lipiddriven inflammatory disease [16]. Collectively, the above chronic disorders are frequently detected in Western societies [17-27]. They are quite problematic for affected patients, as they may induce tissue alterations and progressive tissue destruction (e.g., bone and cartilage destruction in rheumatoid arthritis) or can induce organ failure (e.g., kidney failure in lupus erythematosus) [19, 28]. Furthermore, chronic inflammation may predispose to cancer. In fact, about $20 \%$ of cancer cases in humans are caused by chronic inflammation (e.g., colon cancer in inflammatory bowel diseases) [29, 30]. Moreover, cancer is frequently associated with a chronic inflammatory response in the local microenvironment and such

This article is a contribution to the special issue on Resolution of Inflammation in Chronic Diseases - Guest Editor: Markus Neurath

Markus F. Neurath

markus.neurath@uk-erlangen.de

1 Department of Medicine 1, University of Erlangen-Nuremberg (Friedrich-Alexander Universität Erlangen-Nürnberg), Kussmaul Campus for Medical Research, Ulmenweg 18, 91054 Erlangen, Germany

2 Deutsches Zentrum Immuntherapie (DZI), Erlangen, Germany inflammation may profoundly control tumor growth and prognosis [31-33]. These observations underline the unmet clinical need to gain further detailed insights into the pathomechanisms of chronic inflammation and into the signalling pathways that impair resolution of inflammation.

Studies in recent years have unequivocally shown that resolution of inflammation is an actively controlled process rather than a passive procedure in which the proinflammatory immune cascade in inflammation simply fizzles out. Resolution of inflammation involves highly coordinated actions of various immune and non-immune cells $[1,34]$. Clearance of damaged cells and pro-inflammatory immune cells usually takes place via coordinated processes of cell death such as apoptosis and cell removal such as efferocytosis [35-37]. Additional repair mechanisms may then allow full or at least partial reconstitution of tissue integrity and function. These processes require the tight controlled interaction between various cell types and immune cells such as granulocytes, tissue resident macrophages, innate lymphoid cells, and lymphocytes, and all these cell types have all suggested to play an important role in controlling resolution of inflammation under certain circumstances [37, 38]. Such vital interaction is of utmost importance to foster resolution of inflammation and to achieve tissue homeostasis.

In this special issue of Seminars in Immunopathology, several experts in chronic inflammatory and autoimmune diseases have joined forces to discuss current insights into resolution processes in a variety of key inflammatory disorders [5-16]. They will detail the roles of both innate and adaptive immune cells as well as tissue resident cells in regulating the inflammatory processes and in guiding resolution of inflammation. Moreover, they will discuss the role of soluble mediators in tissue inflammation and healing. In this context, the ratio between specialized pro-resolving and pro-inflammatory mediators emerges as key issue in achieving resolution of inflammation.

Soluble mediators play a crucial role in controlling resolution of inflammation. Specifically, families of pro-resolving 
mediators (SPMs) have been shown to control resolution of inflammation. Key players consist of resolvins, protectins, and maresins that can stimulate self-limited innate responses and enhance innate microbial killing and clearance to protect organ structure and function [39-42]. SPMs thus may actively reprogram the inflammatory process and favor resolution of inflammation. In addition to SPMs, however, other soluble mediators such as cytokines may regulate resolution of inflammation. For instance, cytokines with anti-inflammatory immune function such as IL-10 and TGF-beta are frequently produced during inflammation by macrophages or lymphocytes, respectively [43-46]. In particular, regulatory $\mathrm{T}$ cells (Treg) produce such cytokines that actively suppress inflammatory processes and favor resolution of inflammatory processes $[47,48]$.

In some situations, chronic inflammation may not resolve because of an overwhelming pro-inflammatory immune response that overrides anti-inflammatory signals and mediators [38]. This pro-inflammatory response may involve the production and release of chemical mediators such as vasoactive amines (e.g., histamine), eicosanoids (e.g., leukotrienes), and small peptides (e.g., bradykinin) [49, 50]. Additionally, proinflammatory mediators comprise cytokines such as IFN-gamma, tumor necrosis factor (TNF), and IL-23 [26, 5

$1-55]$. They may amplify inflammatory processes by inducing cell death or activating other local immune cells in the microenvironment. Based on these findings targeting of such proinflammatory mediators and molecules has been tested in clinical trials and is now routinely used in various chronic inflammatory and autoimmune disorders [56-58]. Frequent intervention strategies in clinical routine include anti-TNF antibodies such as infliximab [58], adalimumab [59], certolizumab pegol [60], and golimumab [61], and some of these TNF blockers have been successfully used in disorders such as rheumatoid arthritis, psoriasis, and inflammatory bowel diseases (Crohn's disease, ulcerative colitis). Additionally, the IL-6R inhibitor tocilizumab was approved for therapy of rheumatoid arthritis [62]. Moreover, the BAff inhibitor belimumab has been studied in lupus erythematosus [63], while the B cell inhibitor rituximab [64] that targets the CD20 molecule has been used together with methotrexate for treatment of rheumatoid arthritis. In multiple sclerosis, the CD52 inhibitor alemtuzumab has been tested for clinical therapy [65]. Furthermore, blockers of IL-4, IL-5, or IL-13 signalling such as benralizumab, mepolizumab, or dupilumab [66-70] have been used in patients with allergic asthma. In addition, monoclonal antibodies targeting IL-12/IL23 p40 (e.g., ustekinumab in psoriasis and Crohn's disease [71-73]) or IL-23 p19 (e.g., risankizumab, guselkumab, tildrakizumab in psoriasis $[74,75])$ have reached clinical therapy in a variety of inflammatory disorders. New approaches for therapy of inflammation came by studying immune cell trafficking [76, 77]. In fact, drugs blocking immune cell homing into inflamed tissues such as the alpha4/beta7 integrin blocker vedolizumab are nowadays routinely used for therapy of inflammatory bowel diseases. This drug prevents lymphocyte homing to the inflamed mucosa with subsequent immune cell activation and retention. Finally, S1P1 receptor agonists (e.g., ozanimod) have been shown to control immune cell efflux from lymph nodes and have been tested in multiple sclerosis [78-80]. Collectively, these findings suggest that selective immune cell intervention may block proinflammatory immune processes and foster resolution of inflammation. Novel therapies may allow better therapy of chronic inflammatory diseases and permit to address harder endpoints in clinical trials such as mucosal healing on endoscopy or even histological healing in ulcerative colitis [81, 82]. However, it should be noted only subsets of patients will respond to immunotherapy and thus development of biomarkers or other predictive parameters will be essential to allow personalized medicine in inflammatory disorders. Moreover, marked differences in immunotherapies exist between individual disorders. For instance, while anti-IL-17A blockers such as secukinumab were effective in psoriasis [20], they aggravated mucosal inflammation in patients with Crohn's disease [83] highlighting the concept of tissue-specific mechanisms affecting resolution of inflammation.

In the future, we may expect optimized immunotherapies with new small molecules or antibodies inducing clinical remission or full resolution of inflammation. Evidence in recent years has suggested that targeting several pro-inflammatory pathways simultaneously may be helpful in improving response to therapy. Potential examples include combination therapies of various biological agents, bispecific antibodies with dual targets or inhibitors of Janus kinases that target signalling events via a large number of cytokine receptors [84-86]. In addition, we need more insights into the antiinflammatory signalling pathways to design more efficient pathways. Potential concepts in this context include administration of pro-resolving molecules, small chemical compounds triggering anti-inflammatory pathways or antiinflammatory cytokines [26, 41]. These concepts might also be combined with the above approaches aiming at suppression of pro-inflammatory mediators in order to further optimize clinical therapy of inflammation.

Thus, various established strategies exist to foster the resolution process in chronic inflammatory disorders. In addition, numerous new concepts have entered preclinical studies or early clinical trials and may be used to boost resolution of inflammation in chronic inflammatory and autoimmune disorders in the future.

Funding information This work was supported by the Clinical Research Group 257 CEDER, the SFB1181, the TRR241, the FOR2438 of the Deutsche Forschungsgemeinschaft, the Interdisciplinary Center for Clinical Research (IZKF) and the Emerging Fields Initiative (EFI) of the Friedrich Alexander Universität Erlangen-Nürnberg. 


\section{References}

1. Hanaoka BY, Ithurburn MP, Rigsbee CA, Bridges SL Jr, Moellering DR, Gower B, Bamman M (2019) Chronic inflammation in rheumatoid arthritis and mediators of skeletal muscle pathology and physical impairment: a review. Arthritis Care Res 71(2): 173-177

2. Schenk M, Bouchon A, Seibold F, Mueller C (2007) TREM-1expressing intestinal macrophages crucially amplify chronic inflammation in experimental colitis and inflammatory bowel diseases. J Clin Invest 117(10):3097-3106

3. Salome A, Sasso D'Elia T, Franchini G, Santilli V, Paolucci T (2019) Occupational therapy in fatigue management in multiple sclerosis: an umbrella review. Mult Scler Int 2019:2027947

4. Yoon EL, Cheong WL (2019) Adherence to oral disease-modifying therapy in multiple sclerosis patients: a systematic review. Mult Scler Relat Disord 28:104-108

5. Benezeder T, Wolf P (2019) Resolution of plaque-type psoriasis: what is left behind (and reinitiates the disease). Semin Immunopathol. https://doi.org/10.1007/s00281-019-00766-z

6. Sadik CD, Schmidt E (2019) Resolution in bullous pemphigoid. Semin Immunopathol. https://doi.org/10.1007/s00281-019-00759$\mathrm{y}$

7. Thiagarajan S, Neurath MF, Hildner K (2019) Resolution of acute intestinal Graft-versus-Host Disease. Immunopathol. https:/doi. org/10.1007/s00281-019-00769-w

8. Finotto S (2019) Resolution of allergic asthma. Immunopathol. https://doi.org/10.1007/s00281-019-00770-3

9. Schett $\mathrm{G}$ (2019) Resolution of inflammation in arthritis. Immunopathol. https://doi.org/10.1007/s00281-019-00768-x

10. Boeltz S, Hagen M, Knopf J, Mahajan A, Schick M, Zhao Y, ErfurtBerge C, Rech J, Muñoz L, Herrmann M (2019) Towards a proresolving concept in systemic lupus erythematosus. Semin Immunopathol. https://doi.org/10.1007/s00281-019-00760-5

11. Dokalis N, Prinz M (2019) Resolution of neuroinflammation mechanisms and potential therapeutic options. Semin Immunopathol. https://doi.org/10.1007/s00281-019-00764-1

12. Ruiz F, Vigne S, Pot C (2019) Resolution of multiple sclerosis. Semin Immunopathol. https://doi.org/10.1007/s00281-01900765-0

13. Wildner G, Diedrichs-Möhring M (2019) Resolution of uveitis. Semin Immunopathol:1-10. https://doi.org/10.1007/s00281-01900758-z

14. Schmitt H, Neufert C, Neurath MF, Atreya R (2019) Resolution of Crohn's disease. Semin Immunopathol:1-10. https://doi.org/10. 1007/s00281-019-00756-1

15. Neurath MF, Leppkes M (2019) Resolution of ulcerative colitis. Semin Immunopathol:1-10. https://doi.org/10.1007/s00281-01900751-6

16. Carracedo M, Artiach G, Arnardottir H, Bäck M (2019) The resolution of inflammation through omega-3 fatty acids in atherosclerosis, intimal hyperplasia and vascular calcification. Semin Immunopathol. https://doi.org/10.1007/s00281-019-00767-y

17. Danese S, Fiocchi C (2011) Ulcerative colitis. N Engl J Med 365(18):1713-1725

18. Neurath MF (2019) Targeting immune cell circuits and trafficking in inflammatory bowel disease. Nat Immunol 20:970-979

19. McInnes IB, Schett G (2017) Pathogenetic insights from the treatment of rheumatoid arthritis. Lancet 389(10086):2328-2337

20. Langley RG, Elewski BE, Lebwohl M, Reich K, Griffiths CE, Papp K, Puig L, Nakagawa H, Spelman L, Sigurgeirsson B, Rivas E, Tsai TF, Wasel N, Tyring S, Salko T, Hampele I, Notter M, Karpov A, Helou S, Papavassilis C, E.S. Group, F.S. Group (2014) Secukinumab in plaque psoriasis-results of two phase 3 trials. N Engl J Med 371(4):326-338
21. Leonardi C, Matheson R, Zachariae C, Cameron G, Li L, EdsonHeredia E, Braun D, Banerjee S (2012) Anti-interleukin-17 monoclonal antibody ixekizumab in chronic plaque psoriasis. $\mathrm{N}$ Engl $\mathrm{J}$ Med 366(13): 1190-1199

22. Dharmage SC, Perret JL, Custovic A (2019) Epidemiology of asthma in children and adults. Front Pediatr 7:246

23. Tsokos GC, Lo MS, Costa Reis P, Sullivan KE (2016) New insights into the immunopathogenesis of systemic lupus erythematosus. Nat Rev Rheumatol 12(12):716-730

24. Ruocco G, Rossi S, Motta C, Macchiarulo G, Barbieri F, De Bardi M, Borsellino G, Finardi A, Grasso MG, Ruggieri S, Gasperini C, Furlan R, Centonze D, Battistini L, Volpe E (2015) T helper 9 cells induced by plasmacytoid dendritic cells regulate interleukin-17 in multiple sclerosis. Clin Sci 129(4):291-303

25. Alinaghi F, Calov M, Kristensen LE, Gladman DD, Coates LC, Jullien D, Gottlieb AB, Gisondi P, Wu JJ, Thyssen JP, Egeberg A (2019) Prevalence of psoriatic arthritis in patients with psoriasis: a systematic review and meta-analysis of observational and clinical studies. J Am Acad Dermatol 80(1):251-265 e19

26. Neurath MF (2014) Cytokines in inflammatory bowel disease. Nat Rev Immunol 14(5):329-342

27. Daines L, McLean S, Buelo A, Lewis S, Sheikh A, Pinnock H (2019) Systematic review of clinical prediction models to support the diagnosis of asthma in primary care. NPJ Prim Care Respir Med 29(1):19

28. Lo MS, Tsokos GC (2018) Recent developments in systemic lupus erythematosus pathogenesis and applications for therapy. Curr Opin Rheumatol 30(2):222-228

29. Kiesslich R, Fritsch J, Holtmann M, Koehler HH, Stolte M, Kanzler S, Nafe B, Jung M, Galle PR, Neurath MF (2003) Methylene blueaided chromoendoscopy for the detection of intraepithelial neoplasia and colon cancer in ulcerative colitis. Gastroenterology 124(4): 880-888

30. Terzic J, Grivennikov S, Karin E, Karin M (2010) Inflammation and colon cancer. Gastroenterology 138(6):2101-2114 e5

31. Landskron G, De la Fuente M, Thuwajit P, Thuwajit C, Hermoso MA (2014) Chronic inflammation and cytokines in the tumor microenvironment. J Immunol Res 2014:149185

32. Mlecnik B, Bindea G, Angell HK, Maby P, Angelova M, Tougeron D, Church SE, Lafontaine L, Fischer M, Fredriksen T, Sasso M, Bilocq AM, Kirilovsky A, Obenauf AC, Hamieh M, Berger A, Bruneval P, Tuech JJ, Sabourin JC, Le Pessot F, Mauillon J, Rafii A, Laurent-Puig P, Speicher MR, Trajanoski Z, Michel P, Sesboue R, Frebourg T, Pages F, Valge-Archer V, Latouche JB, Galon J (2016) Integrative analyses of colorectal cancer show immunoscore is a stronger predictor of patient survival than microsatellite instability. Immunity 44(3):698-711

33. Pages F, Mlecnik B, Marliot F, Bindea G, Ou FS, Bifulco C, Lugli A, Zlobec I, Rau TT, Berger MD, Nagtegaal ID, Vink-Borger E, Hartmann A, Geppert C, Kolwelter J, Merkel S, Grutzmann R, Van den Eynde M, Jouret-Mourin A, Kartheuser A, Leonard D, Remue C, Wang JY, Bavi P, Roehrl MHA, Ohashi PS, Nguyen LT, Han S, MacGregor HL, Hafezi-Bakhtiari S, Wouters BG, Masucci GV, Andersson EK, Zavadova E, Vocka M, Spacek J, Petruzelka L, Konopasek B, Dundr P, Skalova H, Nemejcova K, Botti G, Tatangelo F, Delrio P, Ciliberto G, Maio M, Laghi L, Grizzi F, Fredriksen T, Buttard B, Angelova M, Vasaturo A, Maby P, Church SE, Angell HK, Lafontaine L, Bruni D, El Sissy C, Haicheur N, Kirilovsky A, Berger A, Lagorce C, Meyers JP, Paustian C, Feng Z, Ballesteros-Merino C, Dijkstra J, van de Water C, van Lent-van Vliet S, Knijn N, Musina AM, Scripcariu DV, Popivanova B, Xu M, Fujita T, Hazama S, Suzuki N, Nagano H, Okuno K, Torigoe T, Sato N, Furuhata T, Takemasa I, Itoh K, Patel PS, Vora HH, Shah B, Patel JB, Rajvik KN, Pandya SJ, Shukla SN, Wang Y, Zhang G, Kawakami Y, Marincola FM, Ascierto PA, Sargent DJ, Fox BA, Galon J (2018) International 
validation of the consensus immunoscore for the classification of colon cancer: a prognostic and accuracy study. Lancet 391(10135): 2128-2139

34. Taams LS (2018) Inflammation and immune resolution. Clin Exp Immunol 193(1):1-2

35. Zhang S, Weinberg S, DeBerge M, Gainullina A, Schipma M, Kinchen JM, Ben-Sahra I, Gius DR, Yvan-Charvet L, Chandel NS, Schumacker PT, Thorp EB (2019) Efferocytosis fuels requirements of fatty acid oxidation and the electron transport chain to polarize macrophages for tissue repair. Cell metabolism 29(2): 443-456 e5

36. Ballerie A, Lescoat A, Augagneur Y, Lelong M, Morzadec C, Cazalets C, Jouneau S, Fardel O, Vernhet L, Jego P, Lecureur V (2019) Efferocytosis capacities of blood monocyte-derived macrophages in systemic sclerosis. Immunol Cell Biol 97(3):340-347

37. Kourtzelis I, Li X, Mitroulis I, Grosser D, Kajikawa T, Wang B, Grzybek M, von Renesse J, Czogalla A, Troullinaki M, Ferreira A, Doreth C, Ruppova K, Chen LS, Hosur K, Lim JH, Chung KJ, Grossklaus S, Tausche AK, Joosten LAB, Moutsopoulos NM, Wielockx B, Castrillo A, Korostoff JM, Coskun U, Hajishengallis G, Chavakis T (2019) DEL-1 promotes macrophage efferocytosis and clearance of inflammation. Nat Immunol 20(1):40-49

38. Schett G, Neurath MF (2018) Resolution of chronic inflammatory disease: universal and tissue-specific concepts. Nat Commun 9(1):3261

39. Abdolmaleki F, Kovanen PT, Mardani R, Gheibi-Hayat SM, Bo S, Sahebkar A (2019) Resolvins: emerging players in autoimmune and inflammatory diseases. Clin Rev Allergy Immunol

40. Yaribeygi H, Atkin SL, Simental-Mendia LE, Barreto GE, Sahebkar A (2019) Anti-inflammatory effects of resolvins in diabetic nephropathy: Mechanistic pathways. J Cell Physiol

41. Motwani MP, Colas RA, George MJ, Flint JD, Dalli J, Richard-Loendt A, De Maeyer RP, Serhan CN, Gilroy DW (2018) Pro-resolving mediators promote resolution in a human skin model of UV-killed Escherichia coli-driven acute inflammation. JCI insight 3(6)

42. Serhan CN (2017) Treating inflammation and infection in the 21st century: new hints from decoding resolution mediators and mechanisms. FASEB J 31(4):1273-1288

43. Bohm L, Maxeiner J, Meyer-Martin H, Reuter S, Finotto S, Klein M, Schild H, Schmitt E, Bopp T, Taube C (2015) IL-10 and regulatory $\mathrm{T}$ cells cooperate in allergen-specific immunotherapy to ameliorate allergic asthma. J Immunol 194(3):887-897

44. Dardalhon V, Awasthi A, Kwon H, Galileos G, Gao W, Sobel RA, Mitsdoerffer M, Strom TB, Elyaman W, Ho IC, Khoury S, Oukka M, Kuchroo VK (2008) IL-4 inhibits TGF-beta-induced Foxp3+ T cells and, together with TGF-beta, generates IL-9+ IL-10+ Foxp3(-) effector T cells. Nat Immunol 9(12):1347-1355

45. Uhlig HH, Coombes J, Mottet C, Izcue A, Thompson C, Fanger A, Tannapfel A, Fontenot JD, Ramsdell F, Powrie F (2006) Characterization of Foxp3+CD4+CD25+ and IL-10-secreting CD4+CD25+ T cells during cure of colitis. J Immunol 177(9): $5852-5860$

46. Zigmond E, Bernshtein B, Friedlander G, Walker CR, Yona S, Kim KW, Brenner O, Krauthgamer R, Varol C, Muller W, Jung S (2014) Macrophage-restricted interleukin-10 receptor deficiency, but not IL-10 deficiency, causes severe spontaneous colitis. Immunity 40(5):720-733

47. Fantini MC, Becker C, Tubbe I, Nikolaev A, Lehr HA, Galle P, Neurath MF (2006) Transforming growth factor beta induced FoxP3+ regulatory $\mathrm{T}$ cells suppress $\mathrm{Th} 1$ mediated experimental colitis. Gut 55(5):671-680

48. Kumar P, Bhattacharya P, Prabhakar BS (2018) A comprehensive review on the role of co-signaling receptors and Treg homeostasis in autoimmunity and tumor immunity. J Autoimmun 95:77-99
49. Abdulkhaleq LA, Assi MA, Abdullah R, Zamri-Saad M, TaufiqYap YH, Hezmee MNM (2018) The crucial roles of inflammatory mediators in inflammation: a review. Vet World 11(5):627-635

50. Tunctan B, Senol SP, Temiz-Resitoglu M, Guden DS, Sahan-Firat S, Falck JR, Malik KU (2019) Eicosanoids derived from cytochrome P450 pathway of arachidonic acid and inflammatory shock. Prostaglandins Other Lipid Mediat: 106377

51. Feagan BG, Panes J, Ferrante M, Kaser A, D'Haens GR, Sandborn WJ, Louis E, Neurath MF, Franchimont D, Dewit O, Seidler U, Kim KJ, Selinger C, Padula SJ, Herichova I, Robinson AM, Wallace K, Zhao J, Minocha M, Othman AA, Soaita A, Visvanathan S, Hall DB, Bocher WO (2018) Risankizumab in patients with moderate to severe Crohn's disease: an open-label extension study. Lancet Gastroenterol Hepatol 3(10):671-680

52. Feagan BG, Sandborn WJ, D'Haens G, Panes J, Kaser A, Ferrante M, Louis E, Franchimont D, Dewit O, Seidler U, Kim KJ, Neurath MF, Schreiber S, Scholl P, Pamulapati C, Lalovic B, Visvanathan S, Padula SJ, Herichova I, Soaita A, Hall DB, Bocher WO (2017) Induction therapy with the selective interleukin-23 inhibitor risankizumab in patients with moderate-to-severe Crohn's disease: a randomised, double-blind, placebo-controlled phase 2 study. Lancet 389(10080):1699-1709

53. Schett G, Elewaut D, McInnes IB, Dayer JM, Neurath MF (2013) How cytokine networks fuel inflammation: toward a cytokinebased disease taxonomy. Nat Med 19(7):822-824

54. Fischer A, Gluth M, Pape UF, Wiedenmann B, Theuring F, Baumgart DC (2013) Adalimumab prevents barrier dysfunction and antagonizes distinct effects of TNF-alpha on tight junction proteins and signaling pathways in intestinal epithelial cells. Am J Physiol Gastrointest Liver Physiol 304(11):G970-G979

55. Katsanos KH, Papamichael K, Feuerstein JD, Christodoulou DK, Cheifetz AS (2018) Biological therapies in inflammatory bowel disease: Beyond anti-TNF therapies. Clin Immunol

56. Cooper K, Frampton G, Harris P, Rose M, Chorozoglou M, Pickett $\mathrm{K}$ (2018) Reslizumab for treating asthma with elevated blood eosinophils inadequately controlled by inhaled corticosteroids: an evidence review group perspective of a NICE single technology appraisal. Pharmacoeconomics 36(5):545-553

57. Izumo $\mathrm{T}$, Terada $\mathrm{Y}$, Tone $\mathrm{M}$, Inomata $\mathrm{M}$, Kuse $\mathrm{N}$, Awano $\mathrm{N}$, Moriya A, Jo T, Yoshimura H, Furuhata Y (2019) Rapid effects of benralizumab on severe asthma during surgery for residual tumor after advanced lung squamous cell carcinoma treatment with pembrolizumab. Respir Med Case Rep 26:292-295

58. Rutgeerts P, Vermeire S, Van Assche G (2010) Predicting the response to infliximab from trough serum levels. Gut 59(1):7-8

59. Colombel JF, Sandborn WJ, Rutgeerts P, Enns R, Hanauer SB, Panaccione R, Schreiber S, Byczkowski D, Li J, Kent JD, Pollack PF (2007) Adalimumab for maintenance of clinical response and remission in patients with Crohn's disease: the CHARM trial. Gastroenterology 132(1):52-65

60. Deeks ED (2016) Certolizumab Pegol: A review in inflammatory autoimmune diseases, BioDrugs : clinical immunotherapeutics, biopharmaceuticals and gene therapy

61. Sandborn WJ, Feagan BG, Marano C, Zhang H, Strauss R, Johanns J, Adedokun OJ, Guzzo C, Colombel JF, Reinisch W, Gibson PR, Collins J, Jarnerot G, Hibi T, Rutgeerts P (2013) Subcutaneous golimumab induces clinical response and remission in patients with moderate-to-severe ulcerative colitis. Gastroenterology

62. Plushner SL (2008) Tocilizumab: an interleukin-6 receptor inhibitor for the treatment of rheumatoid arthritis. Ann Pharmacother 42(11): $1660-1668$

63. Bangert E, Wakani L, Merchant M, Strand V, Touma Z (2019) Impact of belimumab on patient-reported outcomes in systemic lupus erythematosus: review of clinical studies. Patient Relat Outcome Meas 10:1-7 
64. Tavakolpour S, Alesaeidi S, Darvishi M, GhasemiAdl M, DarabiMonadi S, Akhlaghdoust M, Elikaei Behjati S, Jafarieh A (2019) A comprehensive review of rituximab therapy in rheumatoid arthritis patients. Clin Rheumatol

65. Federle L, Puthenparampil M, Stenta G, Paolo G, Francesco P (2019) Alemtuzumab as rescue therapy in case of multiple sclerosis rebound following Natalizumab break: Clinical case and literature review. Mult Scler Relat Disord 30:262-264

66. Davila Gonzalez I, Moreno Benitez F, Quirce S (2019) Benralizumab: a new approach for the treatment of severe eosinophilic asthma. J Investig Allergol Clin Immunol 29(2):84-93

67. Weir E, Paton J (2019) Mepolizumab in adolescents with severe eosinophilic asthma not eligible for omalizumab: one center's early clinical experience. J Asthma 22:1-4

68. Thibodeaux Q, Smith MP, Ly K, Beck K, Liao W, Bhutani T (2019) A review of dupilumab in the treatment of atopic diseases. Hum Vaccin Immunother 15(9):2129-2139

69. Chia YL, Yan L, Yu B, Wang B, Barker P, Goldman M, Roskos L (2019) Relationship between benralizumab exposure and efficacy for patients with severe eosinophilic asthma. Clin Pharmacol Ther 106(2):383-390

70. Bermejo I, Stevenson M, Cooper K, Harnan S, Hamilton J, Clowes M, Carroll C, Harrison T, Saha S (2018) Mepolizumab for treating severe eosinophilic asthma: an evidence review group perspective of a NICE single technology appraisal. Pharmacoeconomics 36(2):131-144

71. Feagan BG, Sandborn WJ, Gasink C, Jacobstein D, Lang Y, Friedman JR, Blank MA, Johanns J, Gao LL, Miao Y, Adedokun OJ, Sands BE, Hanauer SB, Vermeire S, Targan S, Ghosh S, de Villiers WJ, Colombel JF, Tulassay Z, Seidler U, Salzberg BA, Desreumaux P, Lee SD, Loftus EV Jr, Dieleman LA, Katz S, Rutgeerts P, U.-I.-U.S. Group (2016) Ustekinumab as induction and maintenance therapy for Crohn's disease. N Engl J Med 375(20):1946-1960

72. Kotze PG, Ma C, Almutairdi A, Panaccione R (2018) Clinical utility of ustekinumab in Crohn's disease. J Inflamm Res 11:35-47

73. Sandborn WJ, Gasink C, Gao LL, Blank MA, Johanns J, Guzzo C, Sands BE, Hanauer SB, Targan S, Rutgeerts P, Ghosh S, de Villiers WJ, Panaccione R, Greenberg G, Schreiber S, Lichtiger S, Feagan BG (2012) Ustekinumab induction and maintenance therapy in refractory Crohn's disease. N Engl J Med 367(16):1519-1528

74. Bai F, Li GG, Liu Q, Niu X, Li R, Ma H (2019) Short-Term Efficacy and Safety of IL-17, IL-12/23, and IL-23 Inhibitors brodalumab, secukinumab, ixekizumab, ustekinumab, guselkumab, tildrakizumab, and risankizumab for the treatment of moderate to severe plaque psoriasis: a systematic review and network meta-analysis of randomized controlled trials. J Immunol Res 2019:2546161

75. Banaszczyk K (2019) Risankizumab in the treatment of psoriasis literature review. Reumatologia 57(3):158-162

76. Feagan BG, Rutgeerts P, Sands BE, Hanauer S, Colombel JF, Sandborn WJ, Van Assche G, Axler J, Kim HJ, Danese S, Fox I, Milch C, Sankoh S, Wyant T, Xu J, Parikh A (2013) Vedolizumab as induction and maintenance therapy for ulcerative colitis. N Engl J Med 369(8):699-710
77. Bickston SJ, Behm BW, Tsoulis DJ, Cheng J, MacDonald JK, Khanna R, Feagan BG (2014) Vedolizumab for induction and maintenance of remission in ulcerative colitis. Cochrane Database Syst Rev 8:CD007571

78. Cohen JA, Comi G, Selmaj KW, Bar-Or A, Arnold DL, Steinman L, Hartung HP, Montalban X, Kubala Havrdova E, Cree BAC, Sheffield JK, Minton N, Raghupathi K, Huang V, Kappos L, Investigators RT (2019) Safety and efficacy of ozanimod versus interferon beta-1a in relapsing multiple sclerosis (RADIANCE): a multicentre, randomised, 24-month, phase 3 trial. Lancet Neurol 18: $1021-1033$

79. Comi G, Kappos L, Selmaj KW, Bar-Or A, Arnold DL, Steinman L, Hartung HP, Montalban X, Kubala Havrdova E, Cree BAC, Sheffield JK, Minton N, Raghupathi K, Ding N, Cohen JA, Investigators SS (2019) Safety and efficacy of ozanimod versus interferon beta- $1 \mathrm{a}$ in relapsing multiple sclerosis (SUNBEAM): a multicentre, randomised, minimum 12-month, phase 3 trial. Lancet Neurol 18:1009-1020

80. Cohen JA, Comi G, Arnold DL, Bar-Or A, Selmaj KW, Steinman L, Havrdova EK, Cree BA, Montalban X, Hartung HP, Huang V, Frohna P, Skolnick BE, Kappos L, Investigators RT (2019) Efficacy and safety of ozanimod in multiple sclerosis: Dose-blinded extension of a randomized phase II study. Mult Scler 25(9):1255-1262

81. Neurath MF (2014) New targets for mucosal healing and therapy in inflammatory bowel diseases. Mucosal Immunol 7(1):6-19

82. Battat R, Duijvestein M, Guizzetti L, Choudhary D, Boland BS, Dulai PS, Parker CE, Nguyen TM, Singh S, Vande Casteele N, Pai RK, Feagan BG, Sandborn WJ, Jairath V (2019) Histologic healing rates of medical therapies for ulcerative colitis: a systematic review and meta-analysis of randomized controlled trials. Am J Gastroenterol 114(5):733-745

83. Hueber W, Sands BE, Lewitzky S, Vandemeulebroecke M, Reinisch W, Higgins PD, Wehkamp J, Feagan BG, Yao MD, Karczewski M, Karczewski J, Pezous N, Bek S, Bruin G, Mellgard B, Berger C, Londei M, Bertolino AP, Tougas G, Travis SP (2012) Secukinumab, a human anti-IL-17A monoclonal antibody, for moderate to severe Crohn's disease: unexpected results of a randomised, double-blind placebo-controlled trial. Gut 61(12): $1693-1700$

84. Boleto G, Kanagaratnam L, Drame M, Salmon JH (2019) Safety of combination therapy with two bDMARDs in patients with rheumatoid arthritis: a systematic review and meta-analysis. Semin Arthritis Rheum 49(1):35-42

85. Simpson EL, Ren S, Hock ES, Stevens JW, Binard A, Pers YM, Archer R, Paisley S, Stevenson MD, Herpin C, Ghabri S (2019) Rheumatoid arthritis treated with 6-months of first-line biologic or biosimilar therapy: an updated systematic review and network meta-analysis. Int J Technol Assess Health Care 35(1):36-44

86. Sandborn WJ, Ghosh S, Panes J, Vranic I, Su C, Rousell S, Niezychowski W (2012) Tofacitinib, an oral Janus kinase inhibitor, in active ulcerative colitis. N Engl J Med 367(7):616-624

Publisher's note Springer Nature remains neutral with regard to jurisdictional claims in published maps and institutional affiliations. 